AperTO - Archivio Istituzionale Open Access dell'Università di Torino

\title{
Word Order in the Lindisfarne Glosses?
}

\section{This is the author's manuscript}

Original Citation:

Availability:

This version is available http://hdl.handle.net/2318/136575

since 2019-01-23T10:02:53Z

Terms of use:

Open Access

Anyone can freely access the full text of works made available as "Open Access". Works made available under a Creative Commons license can be used according to the terms and conditions of said license. Use of all other works requires consent of the right holder (author or publisher) if not exempted from copyright protection by the applicable law. 


\author{
Giuseppe Pagliarulo \\ University of Turin \\ e-mail: giuseppe.pagliarulo@unito.it \\ Telephone number: +39-0110919741 \\ Fax: +39-011883876
}

WORD ORDER IN THE LINDISFARNE GLOSSES?

\begin{abstract}
The author examines all instances of independent use of passive and progressive periphrases in the Lindisfarne Glosses. After having classified the relative positioning of their elements according to frequency and having considered it in its co-occurrence with various contextual variables, especially the presence of pronominal subjects, he suggests that the word order of the text's language can be regarded as being predominantly of the OV type, while at the same time showing clear signs of evolution toward the more modern VO pattern.
\end{abstract}

Keywords: Gospel, Lindisfarne Glosses, Anglo-Saxon, Northumbrian, word-order, auxiliaries 
The issue of word order in the tenth-century Northumbrian text of the Lindisfarne Glosses $(L G)$ has never attracted much attention from scholars, for reasons that may seem obvious. Being a literal, word-for-word translation, it is commonly assumed not to offer useful clues for research in the field. Callaway made this clear as early as 1918: "As to the normal order of words, this Northumbrian gloss, like most interlinear translations, gives next to no evidence of value, since, as a rule, the glossator adheres strictly to the order of his Latin original" (Callaway 1918: iv). More recent studies, while acknowledging the $L G$ 's occasional departures from the original's word order, fail to analyze these in a systematic fashion. Ross (1932) explains a number of such departures as the result of the glossator's use of more than one manuscript as a source text, or as plain errors. A more focused approach is that of Nagucka (1997), who, in a study on the gloss to Matthew's Gospel, examines certain cases in which the glossator seems to deliberately violate his otherwise strict adherence to the Latin original in order to meet his native language's constraints and peculiarities: thus, he sometimes reorders the genitive or the adjective, as in Mt 1:1 (dauides sunu for filii dauid) or in Mt 1:18 (of halig gaast for de spiritu sancto), or he uses double negation, something that Latin does not tolerate, as in Mt 9:30 (geseað patte nan nyte for uidete ne quis sciat). Nagucka's analysis is, however, mostly focused on stylistic, not syntactic, aspects of the problem. Other scholars have considered the problem only partially and in passing, in studies devoted to other subjects (see, for instance, de Haas 2006; Kroch-Taylor 1997).

The text, however, deserves the effort, being a major primary source on an otherwise scarcely attested Old English dialect with noteworthy original traits. It is true that an interlinear translation such as the $L G$ is bound to suffer the syntactic influence of the source text in a heavy fashion, but it should also be noted that there are various Latin grammatical and lexical forms for which Old English lacks exact equivalents. In these cases the glossator is effectively forced to take some liberty in interpreting and paraphrasing the original. It seems reasonable that a close look at all 
those cases in which the glossator uses periphrases to render single Latin words will yield precious insights as to the "natural" ordering of elements in the Northumbrian phrase. The present study seeks to fill in some of our gaps in the knowledge of Northumbrian word-order by focusing on all instances in which a single Latin verb is rendered by a participle-copula complex or such a complex is used independently of the source text.

This kind of periphrasis is most frequently used with a preterite participle for rendering the Latin passive, in its periphrastic as well as synthetic forms. A "progressive" periphrasis consisting of a copula and a present participle is also attested (Scheffer 1975). In the $L G$, when used independently, it usually translates the Latin active imperfect tense. Both periphrases may appear in independent subordinate clauses rendering Latin passive infinitives, absolute ablatives, elliptical clauses and other expressions of difficult word-for-word translation. For clarity's sake, they shall be dealt with separately in what follows.

Periphrases consisting of a copula $(\mathrm{C})$ and a preterite participle $(\mathrm{P})$ are abundantly attested in the $L G .802$ independent instances can be found in the whole of the text, and they are distributed thus:

\begin{tabular}{|c|c|c|c|c|c|c|c|}
\hline \multicolumn{2}{|c|}{ Matthew } & \multicolumn{2}{c|}{ Mark } & \multicolumn{2}{c|}{ Luke } & \multicolumn{2}{c|}{ John } \\
\hline Preface & Gospel & Preface & Gospel & Preface & Gospel & Preface & Gospel \\
\hline 34 & 201 & 29 & 106 & 69 & 244 & 42 & 78 \\
\hline
\end{tabular}

Let us now classify these according to typological criteria. Bearing in mind the aim of this study, it seems most useful to distribute cases into four broad categories. The first category will include all cases in which a single Latin verb is translated by a periphrasis showing a P-C order (e. g. confortebatur $=$ gestrenced was, $\mathrm{Lk} 1: 80)$; the second category will include all cases in which a 
single Latin verb is translated by a periphrasis showing a C-P order (e. g. dicitur $=$ is gecuoeden, $\mathrm{J}$ 1:38); the fourth category will include all cases in which a single Latin verb, or a single Latin expression, is translated by a subordinate clause containing a periphrasis of interest (e. g. conuocatis = miððy geceigd weron, $\mathrm{Mk}$ 3:23); the fourth category will include all other cases - cases in which the periphrasis is not used in isolation but a pronominal subject or object, a stranded preposition or any other element is added to it by the glossator (e. g. uocabitur= he bið genemned, Mt 5:19).

\begin{tabular}{|c|c|c|c|c|c|}
\hline \multicolumn{2}{|c|}{} & P-C & C-P & Subordinate clauses & Other cases \\
\hline \multirow{2}{*}{ Matthew } & Preface & 19 & 12 & 1 & 2 \\
\cline { 2 - 6 } & Gospel & 95 & 70 & 8 & 28 \\
\hline \multirow{2}{*}{ Mark } & Preface & 22 & 7 & 16 & 7 \\
\cline { 2 - 6 } & Gospel & 40 & 43 & 8 & 3 \\
\hline \multirow{2}{*}{ Luke } & Preface & 45 & 13 & 34 & 15 \\
\cline { 2 - 6 } & Gospel & 121 & 73 & 5 & 7 \\
\hline \multirow{2}{*}{ John } & Preface & 20 & 16 & 4 & 63 \\
\cline { 2 - 6 } & Gospel & 23 & 44 & 76 & \\
\hline \multicolumn{2}{|c|}{ Total } & 385 & 278 & & \\
\hline
\end{tabular}

These very raw figures may suggest that the P-C order - a typical feature of OV languages is predominant in the $L G$. This would be consistent with the view, now held by many scholars, that Old English is a predominantly or underlyingly OV language. A closer look at the text, however, reveals that there are contexts in which different patterns are numerically stronger.

53 of the 62 occurrences grouped together as "other cases" (our fourth category) are renderings of single Latin verbs or verbal adjectives by periphrases accompanied by a pronominal subject or object (an example of the latter is dimittimini $=$ iuh bið forleten, $\mathrm{J} 3: 18$ ). Of these, 46 
show the addition of a pronominal subject ${ }^{1}$. In 35 cases out of 46 the presence of the pronominal subject is accompanied by fronting of the finite verb and thus a C-P order in the periphrasis (the type turbaris $=ð u$ bist astyred, Lk 10:41), consistently with the tendency, nearly always observed in Old English declarative independent clauses, for the finite verb to occupy the position immediately to the right of the pronominal subject (Fischer et al., 2000: 49). It should be noted, however, that such a pattern is also detectable in the translation of Latin subordinate clauses (e. g. ut baptizarentur = paette hia wero gefuluad, Lk 3:7). This may be a result of the word-for-word technique adopted by the glossator or it may be the signal of a levelling of the pattern throughout clause types, not an uncommon phenomenon in the earliest Middle English documents (Francovich Onesti, 1993: 91). We will return to this issue later.

Only three cases with an added pronominal subject show a P-C order in the periphrasis. One of these is clearly recognizable as a final clause: ut uideantur = pat hia gesene sie, Mt 6:5. In Mt 23:12 we have exaltabitur $=$ he ahafen bið, and in Mt 23:28 paretis $=$ ge gesene bið.

Three of the cases with an added pronominal subject show a C-subject-P order. One of these is immediately preceded by a negative particle: ne turbemini $=$ ne se gie gestyred, Mt 24:6; one is immediately preceded by a WH-word: quid turbamini=forhuon arogie gestyred, Mk 5:34; the third has baptizabimini $=$ se gie gefulwad, Mk 10:39. The most parsimonious explanation for the ordering of elements in Mt 24:6 and Mk 5:34 is that it is due to the influence of the preceding word, as it is an unexceptionable rule of Old English syntax for sentences to show subject-verb inversion in presence of an immediately preceding negative particle or in independent questions (Fischer et al., 2000: 49-50; van Kemenade 1997a: 93). This, however, would imply that the glossator was rather less "mechanical" in his work than one would expect the author of a mere word-for-word gloss to

$1 \quad$ Mt $3: 13,4: 1,5: 19,5: 25,6: 1,6: 2,6: 5,6: 16,6: 18,6: 31,7: 2,8: 25,10: 18,12: 37,12: 37,22: 3,23: 5,23: 10,23: 12$, 23:12, 23:28, 23:34, 24:6, 26:2, 27:26; Mk 5:32, 10:39, 13:9; Lk LXXIIII, XCIIII, 1:74, 3:7, 6:21, 10:41, 12:50, 13:32, $15: 29,21: 12,21: 16,23: 32,24: 49 ; \mathrm{J} 1: 50,14: 28,16: 32,18: 36,21: 18$. 
be. It is therefore pertinent to consider Mt 24:6 in the wider context of all renderings in which a Latin finite verb is translated by a Northumbrian finite verb accompanied by a pronominal subject and it is immediately preceded by a negative particle (e. g. non ueni $=$ ne cuom ic, Mt 5:17). There are 194 such cases ${ }^{2}$. Of these, 182 (94.3\% of the total) show subject-verb inversion. Of the 12 divergent cases, 8 appear to be mechanical translations (the type non sitiam $=$ ne ic $\partial y r s t o, \mathrm{~J} 4: 15$ ) while the others place ne after the subject (the type non habeo = ic ne hafu, J 4:17). In some cases the glossator gives two alternative renderings, a literal one and a "free" one, of the same expression: in $\mathrm{J}$ 4:38 the Latin non ad te pertinet is translated first by ne to ðе byreð and then by ne reces $\partial$. In the only case of conjunctive negation there is no inversion: neque nubent neque nubentur = ne hia maensumiað ne hia biðon gemoensumad (Mk 12:25), the common Old English word order in such cases being SOV. The periphrasis, however, has a C-P order, contrary to the general Old English tendency (see Mitchell 1985: $\$ 3911$ ff.). The presence of the pronominal subject hia probably accounts for this discrepancy, as will be suggested in greater detail in what follows.

Let us now consider all cases in which a Latin finite verb in a "yes/no" question or immediately following an interrogative pronoun or adverb is translated by a Northumbrian finite verb accompanied by a pronominal subject (e. g. quem quaeritis = huoelcne soecas gie, J 18:4).

2 Mt 3:11, 5:17, 5:21, 5:26, 5:36, 6:1, 6:24, 7:3, 8:8, 8:10, 10:23, 10:28; 10:34, 11:17, 11:17, 12:7, 13:13, 13:13, $14: 17,15: 17,14: 24,15: 32,15: 32,16: 3,16: 7,16: 23,17: 27,18: 3,20: 13,20: 22,21: 32,22: 12,23: 10,23: 30,23: 37,24: 44$, $25: 12,25: 13,25: 26,25: 42,25: 42,25: 43,25: 43,25: 43,25: 44,25: 45,26: 29,26: 40,26: 70$; Mk 3:9, 4:13, 4:38, 7:4, 7:18, $8: 2,8: 16,8: 17,8: 18,8: 18,8: 18,8: 33,10: 38,11: 31,12: 14,12: 14,12: 24,12: 25,12: 26,12: 34,13: 33,14: 25,14: 37$, 14:68, 14:68; Lk 1:34, 3:16, 5:32, 6:41, 6:42, 6:46, 7:7, 7:9, 7:32, 7:32, 7:44, 7:45, 7:46, 11:7, 12:17, 12:40, 12:59, 13:7, $13: 25,13: 27,13: 34,14: 20,15: 19,15: 21,16: 2,16: 3,17: 9,18: 4,18: 11,19: 44,21: 14,22: 16,22: 18,22: 53,22: 57,22: 58$, 22:67, 22:68, 22:68, 24:18; J 1:21, 3:8, 3:11, 4:15, 4:15, 4:17, 4:17, 4:48, 5:7, 5:30, 5:38, 5:38, 5:40, 5:41, 5:42, 5:43, 5:44, 6:36, 6:39, 6:53, 7:8, 7:28, 7:34, 7:35, 7:36, 8:14, 8:16, 8:19, 8:41, 8:43, 8:45, 8:49, 8:50, 9:12, 9:21, 9:25, 9:29, $9: 41,10: 26,10: 33,11: 15,11: 50,12: 49,13: 8,13: 8,13: 11,13: 33,13: 36,14: 9,14: 10,14: 11,14: 18,15: 5,15: 15,15: 19$, $16: 1,16: 4,16: 10,16: 12,16: 16,16: 18,16: 23,16: 24,16: 32,17: 11,17: 15,18: 9,18: 17,18: 20,18: 25,18: 36,19: 6,19: 10$, 19:11, 19:15, 19:36, 20:2, 20:13, 20:25, 21:25. Negative interrogatives are excluded. 
There are 110 such renderings ${ }^{3}$. Of these, 92 (83.6\% of the total) show subject-verb inversion (note that the percentage drops to $40.6 \%$ when other elements intervene between the WH-word and the subject). The case numquid ego $=$ hueðer ic see, Mk 14:19, has been counted as a divergent instance but it should be remembered that questions introduced by hueðer do not usually show subject-verb inversion (Fischer et al., 2000: 54; Mitchell 1985: §3895). Inversion is regularly present in negative questions: quare non abduxistis $=$ forhuon ne gebrohtongie, $\mathrm{J} 7: 45$, and the glossator may even find it necessary to independently add a post-verbal pronominal subject in a negative question in which the Latin text puts the subject in preverbal position, as in J 8:46: quare vos non creditis $=$ forhuon gie ne gelefeð gie. In Mk 11:3 and Lk 7:19 tu es (interrogative) is given the alternative renderings $\partial u$ arð and $\operatorname{ar} \succsim \partial u$, the latter obviously against the original's word order. It thus seems quite clear that the glossator did take context into account, though not to a "literary" extent, of course, and that he tried to mediate between his adherence to the source text and the constraints of his own language, sometimes with clumsy results. The ordering of elements in Mt 24:6 and Mk 5:34 can be thus accounted for by normal Old English syntactic rules. In Mk 10:39 the inversion is probably due to the verb being understood as an exhortative form: it is not unusual for the Latin future tense to be rendered by the Northumbrian imperative mood (e. g. geceig $\partial u=$ uocabis, Mt 1:21; worða adorabis, Lk 4:8) and the Northumbrian gloss, like the West Saxon Gospel version, regularly has inversion in renderings of Latin imperatives and in other expressions of command and wish, consistently with general Old English rules (Mitchell 1985: § 3897).

3 Mt 6:31, 6:31, 6:31, 7:4, 8:29, 9:4, 9:28, 11:3, 11:7, 11:8, 11:9, 12:27, 12:34, 12:48, 13:51, 15:16, 16:8, 18:1, 20:21, 20:22, 20:32, 21:16, 23:33, 24:45, 26:15, 26:17, 26:50, 26:53, 27:17, 27:46; Mk 1:24, 2:24, 3:33, 4:41, 5:39, $6: 24,7: 18,8: 17,10: 17,10: 36,10: 38,10: 51,11: 3,11: 5,12: 10,14: 12,14: 19,14: 68,15: 9,15: 34 ;$ Lk 1:65, 2:48, 3:12, $3: 14,4: 30,4: 34,5: 22,6: 2,6: 42,7: 19,7: 24,7: 25,7: 26,7: 44,8: 25,9: 54,10: 26,12: 17,12: 41,12: 42,12: 49,12: 51,13: 2$, $13: 4,16: 3,16: 5,16: 7,18: 8,18: 19,18: 19,19: 31,19: 33,22: 9,22: 46,22: 49,24: 5,24: 41 ; \mathrm{J} 1: 38,1: 38,4: 12,4: 27,4: 27$, $5: 6,5: 44,6: 5,6: 28,6: 30,6: 68,8: 53,11: 26,11: 47,11: 34,14: 5,18: 4,18: 22,18: 25,18: 35,18: 39,21: 5,21: 21$. Negative interrogatives are excluded. 
In the four cases showing $\mathrm{P}$ in initial, apparently topicalizing position (gesald he woere = tradendum, Lk LXXIIII; gefreouad we se = liberati, Lk 1:74; aoehtad gé biðon = persequentur, Lk 16:18; gesáld gie biðon = trademini, $\mathrm{Lk} 21: 16$ ) the finite verb retains its post-subject position, as is common in Old English when the subject is a pronoun, although it should be remembered that Northumbrian seems less coherent than West Saxon in this respect, and the $L G$ do show a few divergent cases such as fulle biðon/aro gie = pleni estis, Mt 23:28. It has been estimated that in 10$20 \%$ of the cases where the Latin text can be interpreted as having a preposed topic, the pronoun subject inverts with the verb in the $L G$ (Kroch-Taylor 1997: 321-322).

Seven of our "other cases" are impersonal passives showing the addition of an indirect pronominal object. The pronoun's position varies. In four cases it comes immediately before the finite verb: him bið onfoen = adsumetur, Mt 24:40; iuh bið forleten = dimittimini, Lk 6:37; iuh bið sald = dabitur $($ uobis), Lk 6:38; ðе sint uncuðo = ignoras, J 3:10. The remaining instances have it immediately before the participle: bið him gesald $=$ fiet $($ ei $)$, Mk 11:23; bið him forgefen $=$ remittetur, Lk 12:10; bið ðe gedoemed = iudicatur, J 3:18. All of these can reasonably be taken as main clauses. The cases from Lk 12:10 and J 3:18 are immediately preceded by $n e$, whose influence on the copula's position cannot be ruled out. It should be noted, apart from that, that in all of these cases the copula appears somewhere left of the participle.

Cases involving stranded prepositions or particles are in is asagd = infertur, Lk XXXVII; inn biðon geladed $=$ inducantur, Mt 24:24; to sie gefylled $=$ adimpleatur, Mt 13:14. The preposition or particle always precedes the whole periphrasis. It is common for the $L G$ glossator correctly or incorrectly to "dismember", as in the quoted cases, prefixed and compound Latin verbs in translating them, giving rise to what might be taken as syntactic calques (compare eft gie toslitas $=$ rescindentes, Mk 7:13; to gebrohte = attulit, Mk 9:17; wel gie doeð= bene-feceritis, Lk 6:33; in ic foerde $=$ intraui, $\mathrm{Lk} 7: 45)$. That the observed positioning of stranded prepositions is not entirely due to Latin influence, however, is shown by such instances as aed he were $=$ esse, Mk 6:55. 
The Preface to Matthew's Gospel contains two cases in which a coordinating conjunction is added to the periphrasis: \& geteled is $=$ referturque $; \&$ ec were gesagd $=$ enarratur. An adverb is added in eft gewoegen bið = remetietur, Mk 4:24; eft forgefen bið = remittetur, Lk 12:10; eft bið gesald $=$ retribuetur, $\mathrm{Lk}$ 14:14; sie eft accenned $=$ renatus, $\mathrm{J}$ VI.

The only case showing the independent addition of a pronominal subject and a noun complement is he on rode were genagled $=$ crucifigeretur, Mt 27:26. The clause is introduced by patte $=u t$ and is clearly a subordinate. Although the periphrasis is found on the right of the complement, as is common in Old English subordinate clauses and would be expected in an OV language, the order of its elements is C-P, contrary to the general Old English tendency (Mitchell 1985: § 3911; Koopman 1992: 322) and typically of VO languages.

Let us now consider those instances in which a single Latin verb is rendered by a Northumbrian subordinate clause containing a periphrasis of interest (our third category).

The glossator is often brought to render the Latin passive infinitive and ablative absolute (as well as, sporadically, other Latin forms) by means of finite subordinates introduced, respectively, by pat(-te) and miððy (e. g. patte sé ofslagen = occidi, Lk 9:22; miððy ofðon was gehered $=$ quo audito, Mk 11:18). Relative clauses may also be independently used to clarify passages (e. g. pat lond ðe is genemned predium $=$ praedium, $\mathrm{Mk} 14: 32$ ). One can count 47 cases like the example from $\operatorname{Lk} 9: 22^{4}, 26$ cases like the example from Mk 11:18 and three passive relative clauses like the 
one from Mk 14:32 (ðe is genemned predium, Mk 14:32; ðe is sua genemned, Mk 12:41; ðio forleteno bið = dimissam, Lk 16:18).

In the 47 final or complement clauses introduced by pat(-te), word order is predominantly C-P, whether a (pronominal) subject is present (e. g. patte ic se gefuluwad = baptizari, Lk 12:50, and 16 other cases) or not. There are only two divergent cases: paet gesendet were $=$ missum, J II; patte ofersuiðet was $=$ superatus, Lk XI. Subordinate clauses introduced by miððy present a much more mixed picture: 17 out of 26 cases (roughly two-thirds of the total) have a P-C order in the periphrasis. None of these has an independent expressed subject, however, and in the only case in which an independent complement is present ( $\mathrm{Mk} 11: 18$, given above), although the complement is on the left of the periphrasis, the periphrasis has a C-P order: the same pattern that has been observed in Mt 27:26.

Let us now consider the cases falling into our first and second categories in the light of these data.

Periphrases immediately preceded by a negative particle (e. g. ne bið forgefen $=$ non remittetur, Mt 12:31) show a strong prevalence of the C-P order, so that the finite verb immediately follows ne, consistently with what has been observed in cases like Mt 24:6. Of the 45 instances $^{6}$ of this kind, only four have a P-C order. Expressions of wish seem to make the C-P pattern preferable, too: the elliptical Latin benedictus is always rendered by the Northumbrian se gebledsod (Mt 21:9, 23:39; Mk 11:9, 11:10; Lk 1:68, 13:35, 19:38; J 12:13) even though it is always and very predictably followed by the noun or pronoun it refers to. Compare these cases to the elliptical beati in the Sermon of the Mount (Mt 5:3-12), which is always rendered by eadge biðon.

$6 \quad$ Mt 12:2, 12:4, 12:31, 12:32, 12:39, 14:4, 16:4, 17:21, 24:2, 24:2, 24:34, Mk 2:24, 4:22, 6:9, 6:18, 7:4, 8:12, 9:44, 9:46, 9:48, 13:2, 13:2, 13:31; Lk 2:26, 6:4, 7:30, 8:17, 8:18, 8:27, 10:42, 11:29, 12:2, 21:6, 21:18, 21:34, 24:23; J $3: 20,5: 10,7: 23,12: 42,14: 1,14: 27,18: 31$. 
The same may be said of periphrases immediately preceded by a pronominal subject (e. g. ic beom gefulwuad $=$ ego baptizor, Mk 10:39). One can count 13 such cases ${ }^{7}$. Only two of these have a P-C order in the periphrasis: the divergent instances are ðés gefroefred bið = hic consolatur, Lk 16:25; ða gefroefred biðon = ipsi consolabuntur, Mt 5:5, the latter introduced by forðon = quoniam and probably meant as a subordinate. Renderings like the one from Mk 10:39 may be compared to ðи arððas ðegn = tu discipulus illius es, $\mathrm{J}$ 9:28; ic am tó ðon accenned $=$ ego in hoc natus sum, $\mathrm{J}$ 18:37: here the glossator is brought to violate his source text's word order to introduce verbseconding in presence of a pronominal subject. In Lk 20:16 we find a rendering that seems particularly interesting. Here the ablative absolute quo audito is translated, as usual, by a finite subordinate clause: miððy paet waes gehered. The periphrasis shows a C-P order, which, as we have seen, is not the majority pattern for subordinates introduced by miððy. This particular rendering finds an exact parallel in miððy ðas woeron gecuedno = his dictis, Lk 19:28. This, along with what we have observed in independently formed subordinates like the example from Lk 12:50, above, makes it tempting to say that the presence of a (pronominal) subject plays some role in the fronting of the finite verb even in subordinates like these, which would be another early sign of the levelling of the word order pattern throughout clause types observed in later English.

33 periphrases of interest are immediately preceded by pat(-te) $=u t^{8}$ (e. g. patte sie gefylled $=$ ut adimpleretur). The $\mathrm{C}-\mathrm{P}$ order has a slight majority in these cases, with 18 instances against 15 instances of P-C. But again, note that when a pronominal subject is independently added in such a rendering (e. g. paette hia wero gefuluad $=$ ut baptizarentur, Lk 3:7, and even pat ðu ne se gesene = ne uidearis, Mt 6:18) the C-P order prevails greatly: of 13 such renderings ${ }^{9}$, only one shows a P-C

$7 \quad$ Mt 5:5, 26:9; Mk, 10:38, 10:39; Lk 5:38, 16:25, 16:25, 18:14, 19:28, 20:16; J 1:42, 13:14, 21:25.

$8 \quad$ Mt 1:22, 2:22, 2:23, 4:14, 5:13, 8:17, 12:17, 13:35, 20:33, 21:4, 26:56, 27:35; Mk 10:38, 12:33, 15:15; Lk 2:21, 3:12, 9:44, 11:50, 14:23, 21:22, 23:23; J 1:31, 3:17, 3:21, 9:2, 11:4, 12:23, 13:18, 14:13, 15:25, 18:9, 19:16, 19:28. 
order (Mt 6:5, already mentioned). In three cases ( $\operatorname{Lk} 3: 21,9: 51,22: 45)$ the periphrasis is immediately preceded by miððy $=c u m / d u m$. All three have a P-C order. In 52 cases $^{10}$ the periphrasis is immediately preceded by a relative pronoun (e. g. ðaðe gihaled biðon=qui saluantur, Lk 13:23). The P-C order is represented in 28 of these against 23 instances with C-P, and in one instance two contrasting renderings are given: ðaðe geswoenced woere / weron geswoencde = qui uexabantur, Mk 1:34. It thus seems that the glossator hesitates a lot in such cases, so that no particular ordering of elements neatly prevails over the other: the hesitation is also evident in alternative renderings like pat we sie dead / pat we deado sie = quia perimus, Mk 4:38. Such a distribution of C-P and P-C clusters in these subordinates is, however, interestingly similar to that observed by Koopman in the works of Ælfric and in the Alfredian translation of the Cura Pastoralis (Koopman 1992: 320).

This is what seems possible to say considering the contextual elements that have the highest probability of influencing the periphrasis's word order. Let us now turn to periphrases consisting of a copula and a present participle (e. g. foerende was = egrediebatur, Mk 1:5). These are independently attested in 90 cases, which are distributed thus:

\begin{tabular}{|c|c|c|c|c|c|}
\hline \multicolumn{2}{|c|}{} & P-C & C-P & Subordinate clauses & Other cases \\
\hline \multirow{2}{*}{ Matthew } & Preface & 1 & 1 & 0 & 0 \\
\cline { 2 - 6 } & Gospel & 14 & 4 & 3 & 3 \\
\hline \multirow{2}{*}{ Mark } & Preface & 0 & 1 & 0 & 0 \\
\cline { 2 - 6 } & Gospel & 15 & 7 & 1 & 4 \\
\hline
\end{tabular}




\begin{tabular}{|c|c|c|c|c|c|}
\multirow{3}{*}{ Luke } & Preface & 1 & 2 & 1 & 1 \\
\cline { 2 - 6 } & Gospel & 9 & 7 & 1 & 1 \\
\hline \multirow{2}{*}{ John } & Preface & 0 & 0 & 0 & 0 \\
\cline { 2 - 6 } & Gospel & 7 & 3 & 1 & 11 \\
\hline \multicolumn{2}{|c|}{ Total } & 47 & 25 & 7 & 2 \\
\hline
\end{tabular}

Again, the raw numbers are in favour of the P-C pattern. However, the contextual variables we have contemplated seem to exert their influence here too.

Nine of the "other cases" show the independent addition of a pronominal subject (e. g. he was spracend = loquebatur, Mk 8:32). In seven of these $($ Mt 13:1, 17:5, 21:9; Mk 3:11, 8:32, 11:25; J 11:19) the periphrasis has a C-P order, even when a subordinating conjunction precedes (paette hia uoero gefroefrende $=$ ut consolarentur, J 11:19), the exceptions being the relative clause ðaðe he wyrcende was = quae faciebat, Mk 3:8, and biðongie hyngrendo = esurietis, Lk 6:25 perhaps an instance of emphatic inversion. It is interesting to compare these renderings to hiu waes wyrcenda $=$ operata est, Mt 26:10; hia wero sprecendo $=$ locuturi sint, Lk LI, where the glossator seems again driven to violate the original's word order to let the copula immediately follow the subject. In one case the glossator renders the Latin praecedebat by onfora was geongend, Mk $10: 32$.

The only instance in which the periphrasis is part of a subordinate clause introduced by patte shows a P-C order: patte bodande wero = praedicaturus, Lk XXXIII. Four renderings in which subordinate clauses introduced by miððy are independently used can be counted: miððy wutedlice was he útgeongende $=$ exeunte autem illo, Mt 26:71; miððy was faerende $=$ egressus, Lk 22:39; miððy he was sprecende $=$ illo loquente, $\mathrm{J}$ 8:30; miððy farende weron $=$ exeuntes, $\mathrm{J}$ 5:13. The instance from Mt 26:71 is of great interest, as it shows a case of verb-seconding with an adverb in 
initial position, a common phenomenon in Old English main clauses - though not with pronominal subjects, as in this case - but a very unusual one in subordinates, where V2 is only found after bridge verbs (van Kemenade 1997b: 333). In J 8:30 we observe again the fronting of the finite verb in presence of a pronominal subject, as in Lk 19:28, 20:16 etc. Even more interesting is fylgende hine woere $=$ secuturus, Lk XXXVII. This is found in the translation of the Latin docet ut eum quisque secuturus abneget semet ipsum, rendered, somewhat confusedly, thus: lareð patte hine aelc/sua hualc fylgende hine woere onsaca hine seolfne. The rendering is interesting because the pronominal object is placed after the non-finite verb - a very infrequent and innovative pattern found only in texts later than 950 (Fischer et al. 2000: 142) - and because the periphrasis shows a P ... C pattern, which is extremely rare, if not unique ("the fourth possibility (V ... v) does not occur", Koopman 1992: 319) ${ }^{11}$.

The C-P pattern appears again with a pronominal subject in the only independently formed subordinate introduced by ða: ða hia weron farend = egressis, Mt 9:32. An ambiguous case is ðende was he spreccende $=$ athuc illo loquente, Mt 26:47. Here ðende probably functions as an adverb, as the subject-copula inversion shows.

The only case with an exhortative function shows a C-P pattern: waes milsende = misertus, Mk 9:22. Two periphrases are preceded by a negative particle and, as we would expect, they show a C-P pattern: $n e$ is sellennde $=$ non dandum, Mt XXII; ne waes spreccend $=$ non loquebatur, $\mathrm{J}$ 4:34. The periphrasis is immediately preceded by pat $=u t$ in pat fore-ondetande weron $=u t$ profiterentur, Lk 2:3, and by miððy = cum/dum in miððy gehatend was $=$ cum iussisset, Mt 14:19; miððy stigende weron $=$ cum ascendissent, Mt 14:32; miððy gie biðon stondende $=$ cum stabitis, Mk 11:25 (note the pronominal subject); miððy was farende = cum processisset, Mk 14:35; miððy woeron spellendo=

11 After writing this article I became aware that a similar case is found in the fifth Blickling Homily (Dominica $V$ in Quadragesima), 40.72-75 in Richard J. Kelly's edition: forpon hi ne besceawiap [...] on hwylcum sare hi acennede fram medder warun. I am grateful to dr. Giuseppe Donato De Bonis for pointing this out to me. 
dum fabularentur, Lk 24:15. A relative pronoun precedes the periphrasis in patte cuoeðend was $=$ quod dixerat, Mk 14:72; ðaðe bidendo woeron = qui expectabant, Lk 2:38.

It seems that three points can be made in the light of what we have observed. The first is that the glossator didn't carry out his work on a purely word-for-word basis but he took context into account to an appreciable degree. The second is that he seems to show a preference for the P-C pattern except when certain contextual elements - most interestingly, the presence of a pronominal subject - drive him to adopt different solutions, and that these elements seem to exert their influence regardless of the clause type in which they are found. The third is a consequence of the second: the $L G$ seem to show the signs of a levelling out of word order distinctions between subordinate and main clauses, thus anticipating a development that would become evident in the Middle English period.

This analysis, as I stated, is partial, and I do not doubt that I have missed many contextual variables that can be usefully considered in relation to periphrastic patterns in the text. Further research is clearly required, and I hope that this paper may serve as motivation for new studies.

\section{EDITION}

Skeat, Walter W. (ed.),

The Gospel according to Saint Matthew and according to Saint Mark, Cambridge, 18711887.

The Gospel according to Saint Luke and according to Saint John, Cambridge, 1874-1878. 


\section{REFERENCES}

Callaway, Morgan Jr. (1918). Studies in the Syntax of the Lindisfarne Gospels, Baltimore: The Johns Hopkins University Press.

Fischer, Olga - van Kemenade, Ans - Koopman, Willem - van der Wurff, Wim (2000). The syntax of Early English, Cambridge: University Press.

Francovich Onesti, Nicoletta (1993). "Verb Syntax in the Peterborough Chronicle (1132-54)", in: Gotti (ed.), 89-110.

Gotti, Maurizio (ed.) (1993). English diachronic syntax, Milano: Guerini.

Gotti, Maurizio - Dossena, Marina - Dury, Richard (eds.) (2006). English historical linguistics 2006: selected papers from the fourteenth international conference on English historical linguistics, Bergamo, 21-25 August 2006, Amsterdam: John Benjamins.

de Haas, Nynke (2006). "The Origin of the Northern Subject Rule”, in: Gotti - Dossena -Dury (eds.), 111-130.

van Kemenade, Ans (1997a). "Negative-initial sentences in Old and Middle English”, Studia Anglica Posnaniensia 31, 91-104.

van Kemenade, Ans (1997b). "V2 and embedded topicalization in Old and Middle English”, in: van Kemenade - Vincent (eds.), 326-352.

van Kemenade, Ans - Vincent, Nigel (eds.) (1997). Parameters of Morphosyntactic Change, Cambridge: University Press.

Koopman, Willem (1992). "The distribution of verb forms in Old English subordinate clauses", in: Rissanen - Ihalainen - Nevalainen - Taavitsainen (eds.), 319-335.

Kroch, Anthony - Taylor, Ann (1997). "Verb Movement in Old and Middle English: Dialect Variation and Language Contact”, in: van Kemenade - Vincent (eds.), 45-68. 
Mitchell, Bruce (1985). Old English Syntax, Oxford: University Press.

Nagucka, Ruta (1997). "Glossal Translation in the Lindisfarne Gospel according to Saint Matthew", Studia Anglica Posnaniensia 31: 179-201.

Rissanen, Matti - Ihalainen, Ossi - Nevalainen, Terttu - Taavitsainen, Irma (eds.) (1992). History of Englishes: New Methods and Interpretations in Historical Linguistics, Berlin-New York: de Gruyter.

Ross, Alan S. C. (1932). "The Errors in the Old English Gloss to the Lindisfarne Gospels", The Review of English Studies 32: 385-394.

Scheffer, Johannes (1975). The progressive in English, Amsterdam-New York: North HollandElsevier. 